\title{
Effect of the dietary fibre content of lifelong diet on colonic cellular proliferation in the rat
}

\author{
C A Edwards, R G Wilson, L Hanlon, M A Eastwood
}

\begin{abstract}
The effect of the fibre content of lifelong (18 months) diets on proximal and distal colonic cellular proliferation and short chain fatty acid (SCFA) content was investigated in $\mathbf{4 0}$ rats. Rats were fed a low fibre diet $(17 \mathrm{~g} / \mathrm{kg}$ nonstarch polysaccharides NSP) or the stock diet $(133 \mathrm{~g} / \mathrm{kg}$ NSP). The higher fibre fed rats had increased caecal and colonic total contents $(p<0.001)$ and SCFAs than the low fibre fed rats (caecal SCFAs: higher fibre rats $96.4(6.8)$ $\mu \mathrm{mol} / \mathrm{g}$ wet weight $v$ low fibre 22.7 (3.0): $\mathrm{p}<\mathbf{0 . 0 0 1}$, colonic SCFAs: higher fibre $\mathbf{5 2 . 3}$ (3.1) $\mu \mathrm{mol} / \mathrm{g}$ wet weight $v$ low fibre $6.9(2 \cdot 2)$ $\mu \mathrm{mol} / \mathrm{g}$ wet weight: $\mathbf{p}<\mathbf{0 . 0 0 1})$. Cellular proliferation was increased in the proximal colon (bromodeoxyuridine labelling index, higher fibre $9.3 v$ low fibre $8.4 \mathrm{p}<0.05$; flow cytometry, \% cells in $\mathrm{S}$ phase higher fibre diet $7.9 v$ low fibre 6.9; $p<0.01$ ) and there was a shift of proliferating cells to a higher region in each crypt. There was no significant difference in the percentage of cells in $S$ phase in the distal colon of rats in both diet groups. The proliferative zone, however, was expanded in the distal colon of the higher fibre diet fed rats. This study indicates that long term higher fibre intake in rats is associated with a modest increase in cellular proliferation in the proximal colon but not the distal colon.

(Gut 1992; 33: 1076-1079)
\end{abstract}

It has now been shown by several laboratories that ingestion of fibre causes an increase in cellular proliferation in the colon of rats. ${ }^{12}$ This is probably related to an increase in the exposure of the colonic epithelial cells to short chain fatty acids (SCFA), which in addition to being a possible energy source ${ }^{3}$ for the cells, may also promote cellular proliferation. ${ }^{+}$Most studies, however, have looked at short term ingestion of isolated dietary fibres compared with elemental diets and some have measured the effects of post starvation recovery. ${ }^{2}$ In this study, we have fed rats diets containing $133 \mathrm{~g} / \mathrm{kg}$ non-starch polysaccharides (NSP) or $17 \mathrm{~g} / \mathrm{kg}$ NSP for 18 months, equivalent to lifelong ingestion in man, and have measured both cellular proliferation and colonic SCFA.

Although increased cellular proliferation does not necessarily relate to carcinogenesis, some researchers have suggested the use of increased cellular proliferation as a marker of cancer risk in $\operatorname{man}^{56}$ and since some dietary fibres have been shown to increase colonic cellular proliferation and to increase tumour yield in animal models of colon cancer ${ }^{17}$ the effect of fermentable fibre on cellular proliferation may be a cause of concern. The relevance of these animal models is difficult to assess, as by using carcinogens such as 1,2 dimethylhydrazine (DMH) they concentrate on the final development of the tumour and not on the previous initiating stages of this long multistage process. Dietary fibre may have more inhibitory actions earlier in the process.

Since Deschner and Maskens ${ }^{8}$ have suggested that abnormalities in the distribution of $S$ phase cells within the proliferative compartment of the colonic crypts are important in defining the degree of cancer risk in high colon cancer risk patients, we have measured the distribution of cells in $S$ phase in addition to the overall numbers of $S$ phase cells in each crypt in this study.

\section{Methods}

Forty male Wistar rats, caged in groups of five, were maintained on the test diets for 18 months and were housed on refined cat litter to prevent them eating the bedding. There were 20 rats in each diet group, fed either a low fibre diet (Special Diet Services Ltd, Whitam) containing $17 \mathrm{~g} / \mathrm{kg}$ non-starch polysaccharide (NSP $12 \mathrm{~g} / \mathrm{kg}$ soluble NSP), $124 \mathrm{~g} / \mathrm{kg}$ digestible protein, 801 $\mathrm{g} / \mathrm{kg}$ digestible carbohydrate, $20 \mathrm{~g} / \mathrm{kg}$ lipid, and vitamin and mineral mixes at $55 \mathrm{~g} / \mathrm{kg}$ providing $2990 \mathrm{cal} / \mathrm{kg}$, or a higher fibre diet (CRMX; Labsure Ltd) containing $133 \mathrm{~g} / \mathrm{kg} \mathrm{NSP}(31 \mathrm{~g} / \mathrm{kg}$ soluble fibre), $205 \mathrm{~g} / \mathrm{kg}$ digestible protein, 569 $\mathrm{g} / \mathrm{kg}$ digestible carbohydrate, $24 \mathrm{~g} / \mathrm{kg}$ lipid, and $63 \mathrm{~g} / \mathrm{kg}$ vitamin and mineral mixes providing $2885 \mathrm{cal} / \mathrm{kg}$. (NSP measured by Englyst method. ${ }^{9}$ ) The rats were bred specifically for this study and the parents of experimental animals were fed the appropriate diet for one month before mating.

After 18 months, the rats were killed by overdose of ether. After death, the caecum and colonic contents were collected, weighed wet, and then freeze dried and reweighed. SCFA in the caecal and colonic contents of 10 rats in each group were analysed by gas liquid chromatography. ${ }^{10}$ The caecum and colon were then carefully dissected and divested of fat, rinsed in isotonic saline, blotted, and weighed.

\section{COLONIC MUCOSAL PROLIFERATION}

This was assessed by two methods which measured the number of colonic cells in $S$ phase of the growth cycle. Five rats from each group were given an intraperitoneal injection of $50 \mathrm{mg} /$ $\mathrm{kg}$ bromodeoxyridine (BrdUrd) one hour before death. After death, $1 \mathrm{~cm}$ sections of proximal $(1 \mathrm{~cm}$ from caecum) and distal colon $(2 \mathrm{~cm}$ from anal sphincter) were removed from all animals for cell proliferation analysis. The colonic segments were fixed in Carnoy's fixative and processed to paraffin. For BrdUrd analysis" $3 \mu \mathrm{m}$ sections were taken through the vertical crypt 
TABLE I The effect of 18 months of low fibre and higher fibre diets on the caecal and colonic tissue and contents weights of rats

\begin{tabular}{|c|c|c|c|}
\hline & $\begin{array}{l}\text { Low fibre diet } \\
\text { Mean (SEM) }\end{array}$ & $\begin{array}{l}\text { High fibre diet } \\
\text { Mean }(S E M)\end{array}$ & $p$ \\
\hline $\begin{array}{l}\text { Caecal tissue: } \\
\text { Weight (g) }\end{array}$ & $1 \cdot 17(0 \cdot 02)$ & $1 \cdot 28(0 \cdot 02)$ & $<0.001$ \\
\hline Caecal contents: & & & \\
\hline Wet weight $(\mathrm{g})$ & $3 \cdot 56(0 \cdot 24)$ & $5.93(0 \cdot 19)$ & $<0.001$ \\
\hline $\begin{array}{l}\text { Dry weight (g) } \\
\% \text { Water }\end{array}$ & $1 \cdot 35(0 \cdot 13)$ & $1.9(0.08)$ & $\begin{array}{l}<0.01 \\
<0.01\end{array}$ \\
\hline $\begin{array}{l}\% \text { Water } \\
\text { Colonic tissue: }\end{array}$ & $62 \cdot 0(1 \cdot 65)$ & $67 \cdot 9(0 \cdot 8)$ & $<0.01$ \\
\hline $\begin{array}{l}\text { Weight (g) } \\
\text { Colonic contents: }\end{array}$ & $1.4(0.02)$ & $2.05(0.07)$ & $<0.001$ \\
\hline Wet weight (g) & $2 \cdot 05(0 \cdot 2)$ & $3 \cdot 56(0 \cdot 31)$ & $<0.001$ \\
\hline Dry weight (g) & $1.09(0.16)$ & $1.56(0.15)$ & $<0.05$ \\
\hline$\%$ Water & $55 \cdot 3(5 \cdot 1)$ & $56 \cdot 1(1 \cdot 46)$ & NS \\
\hline
\end{tabular}

$\mathrm{p}$ Values refer to Student's unpaired $t$ test comparing higher fibre with low fibre fed rats.

TABLE II Short chain fatty acid (SCFA) content of caecal and colonic contents of rats fed lifelong (18 months) low or higher fibre diets $(n=10)$

\begin{tabular}{|c|c|c|c|}
\hline & $\begin{array}{l}\text { Low fibre diet } \\
\text { Mean (SEM) }\end{array}$ & $\begin{array}{l}\text { Higher fibre diet } \\
\text { Mean }(S E M)\end{array}$ & $p$ \\
\hline \multicolumn{4}{|l|}{ Caecal contents } \\
\hline \multicolumn{4}{|l|}{ Total SCFA: } \\
\hline$\mu \mathrm{mol} / \mathrm{g}$ dry wt & $\begin{array}{l}60 \cdot 2(10 \cdot 3) \\
22 \cdot 7(3 \cdot 0)\end{array}$ & $\begin{array}{c}296.6(18.4) \\
96.4(6.8)\end{array}$ & $\begin{array}{l}<0.001 \\
<0.001\end{array}$ \\
\hline Total $\mu \mathrm{mol} / \mathrm{caecum}$ & $88 \cdot 4(12 \cdot 9)$ & $\begin{array}{l}90.4(0.8) \\
597(49 \cdot 6)\end{array}$ & $\begin{array}{l}<0.001 \\
<0.001\end{array}$ \\
\hline \multicolumn{4}{|l|}{ Molar proportions: } \\
\hline Acetic & $700(12)$ & $619(14)$ & NS \\
\hline Propionic & $161(9 \cdot 7)$ & $130(12)$ & $<0.01$ \\
\hline Butyric & $59(4)$ & $203(5 \cdot 3)$ & $<0.001$ \\
\hline Isobutyric & $30(2)$ & $28(5 \cdot 3)$ & NS \\
\hline Valeric & $32(2)$ & $16(3)$ & $<0.001$ \\
\hline Isovaleric & 19 (1) & $6(0 \cdot 7)$ & $<0.001$ \\
\hline \multicolumn{4}{|l|}{ Colonic contents } \\
\hline \multicolumn{4}{|l|}{ Total SCFA: } \\
\hline$\mu \mathrm{mol} / \mathrm{g}$ dry wt & $24 \cdot 7(3 \cdot 5)$ & $135 \cdot 9(12 \cdot 1)$ & $<0.001$ \\
\hline$\mu \mathrm{mol} / \mathrm{g}$ wet $\mathrm{wt}$ & $6.9(2 \cdot 2)$ & $52 \cdot 3(3 \cdot 1)$ & $<0.001$ \\
\hline Total $\mu \mathrm{mol} /$ colon & $19.9(5.9)$ & $168(19 \cdot 8)$ & $<0.001$ \\
\hline \multicolumn{4}{|l|}{ Molar proportions: } \\
\hline Acetic & $640(36)$ & $715(21)$ & NS \\
\hline Propionic & $121(6 \cdot 4)$ & $104(13)$ & NS \\
\hline Butyric & $63(6 \cdot 5)$ & $146(14 \cdot 8)$ & $<0.001$ \\
\hline Isobutyric & $59(9 \cdot 7)$ & $10(1)$ & $<0.001$ \\
\hline Valeric & $42(5 \cdot 5)$ & $15(1 \cdot 7)$ & $<0.001$ \\
\hline Isovaleric & $62(11 \cdot 3)$ & $8 \cdot 4(0 \cdot 7)$ & $<0.001$ \\
\hline
\end{tabular}

$\mathrm{p}$ Values relate to Student's $t$ test, higher fibre diet rats compared with low fibre diet rats.

axis at intervals of $100 \mu \mathrm{m}$ and plated onto Poly L-lysine coated slides for subsequent immunostaining. Sections were immunostained with mouse anti-BrdUrd antibody (BectonDickinson) at a dilution of 1 in 400 , visualised with diaminobenzidine, and counterstained with Myer's haematoxylin. The sections were scored blind for Brd Urd labelling. Sections were scored at the original magnification $\times 400$ for the number of stained cells along each crypt. Forty crypt columns were analysed for each section of colon." Since the colonic tissue was to be analysed by $x$ ray diffraction for another study, BrdUrd could not be used in all animals as we had not established that the label had no effect on $x$ ray scatter, therefore similar segments of colon to those described above were taken from all 40 rats and the DNA content of the epithelium analysed by flow cytometry. Colonic epithelium was shed after incubation in EDTA solution using the method of Bjerkness and Cheng ${ }^{12}$ and fixed in $50 \%$ ethanol. Nuclear suspensions were then prepared by digestion of the fixed epithelium in $0.5 \%$ pepsin solution $(\mathrm{pH} 1.5)$ at $37^{\circ} \mathrm{C}$ for 30 minutes. After washing and filtration, the nuclei were stained in propidium iodide solution ( 50 $\mu \mathrm{g} / \mathrm{ml})$ containing RNAase $(1 \mathrm{mg} / \mathrm{ml})$ for 30
TABLE III Effect of lifelong (18 months) feeding low and higher fibre diets to rats on colonic crypt cell proliferation, measured by flow cytometry and bromodeoxyuridine (BrdUrd) labelling index

\begin{tabular}{|c|c|c|c|}
\hline & $\begin{array}{l}\text { Low fibre diet } \\
\text { Mean (SEM) }\end{array}$ & $\begin{array}{l}\text { Higher fibre diet } \\
\text { Mean }(S E M)\end{array}$ & $p^{\star}$ \\
\hline \multicolumn{4}{|l|}{ Crypt cell count } \\
\hline Proximal colon & $28 \cdot 7(0 \cdot 3)$ & $31 \cdot 1(0 \cdot 3)$ & $<0.01$ \\
\hline Distal colon & $30 \cdot 9 \ddagger(0 \cdot 3)$ & $33 \cdot 5 \ddagger(0 \cdot 3)$ & $<0.01$ \\
\hline \multicolumn{4}{|l|}{$\begin{array}{l}\text { BrdUrd labelling index } \\
(n=5)\end{array}$} \\
\hline Proximal colon & $8 \cdot 4(0 \cdot 27)$ & $9 \cdot 3(0 \cdot 32)$ & $<0.05$ \\
\hline Distal colon & $7 \cdot 6+(0.25)$ & $7 \cdot 9+(0 \cdot 30)$ & NS \\
\hline \multicolumn{4}{|l|}{$\begin{array}{l}\text { Flow cytometry } \\
(\mathbf{n}=20)\end{array}$} \\
\hline \multicolumn{4}{|l|}{$\%$ Cells in $\mathrm{S}$ phase: } \\
\hline Proximal colon & $6.9(0 \cdot 32)$ & $7 \cdot 9(0.39)$ & $<0.01$ \\
\hline Distal colon & $6.8(0.27)$ & $7 \cdot 4(0.27)$ & NS \\
\hline
\end{tabular}

${ }^{\star} \mathrm{p}$ Values relate to Student's $t$ test higher fibre group compared with low fibre group.

tProximal colon compared with distal colon.

$t p<0.05, \neq p<0 \cdot 01 ;$ proximal colon compared with distal colon.

minutes at $4^{\circ} \mathrm{C}^{13}$ and analysed in an EPICS CS flowcytometer (Coulter Corporation). DNA histograms were collected for $3 \times 10^{+}$nuclei and the proportion of cells in $S$ phase calculated using a linear $S$ phase fitting programme. ${ }^{1+}$ This was well correlated with the values obtained from those with BrdUrd labelling in the 10 rats in whom both methods were used $(r=0.72$, $\mathrm{p}=0.001$ ).

\section{STATISTICAL ANALYSIS}

Results of the low fibre and higher fibre diet animals were compared by Student's $t$ test. Differences between the cumulative BrdUrd labelling distributions of the colonic crypts of both groups were analysed by two sample, two tailed Kolmogorov-Smirnov test. ${ }^{13}$

\section{Results}

Rats fed the higher fibre diet weighed less (at 18 months; higher fibre rats $570 \mathrm{~g} \mathrm{(26)} v$ low fibre rats $675(28) \mathrm{g}$ ) and were more healthy than the low fibre fed rats. At post mortem, the low fibre diet rats had more abnormalities and tumours of body tissue than the higher fibre diet rats. The higher fibre rats had eight testicular tumours and one mesenteric lesion. In the low fibre group there were six rats with nodular and reticulated lungs, 14 with pale or nodular livers, eight with a pale or nodular pancreas, and 12 rats with testicular tumours. Eight rats were so obese that they developed anterior abdominal wall abrasions. There was also a higher incidence of diverticulosis in the low fibre diet rats $(41 \cdot 2 \% v 0 \%)$. Three rats in the low fibre diet group suffered from middle ear infections and were removed from the study.

\section{CAECAL AND COLONIC CONTENTS}

The wet weight of caecal contents was significantly less in the low fibre compared with the higher fibre diet rats (Table $\mathrm{I}, \mathrm{p}=0.001$ ). Dry weight, however, was not changed. The proportion of water was therefore significantly less in the low fibre group (Table I). The concentration and total amount of caecal and colonic SCFAs were less in the low fibre diet rats (Table II, 


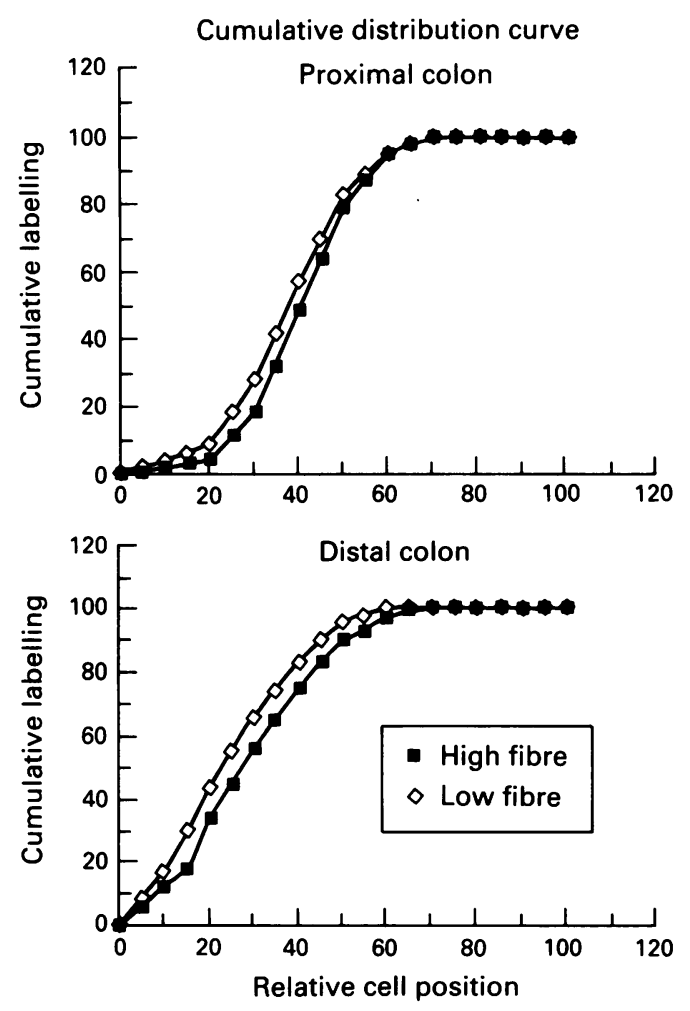

The cumulative labelling of cells in $S$ phase by bromodeoxyuridine (BrdUrd) along the length of colonic crypts in the proximal and distal colon of rats fed low or higher fibre diets. Curves show the cumulative number of cells in $S$ phase progressing up the crypt towards the lumen. A shift in the curve to the right indicates an expansion of the proliferative zone with $S$ phase cells appearing further up the crypt.

$\mathrm{p}=0.001)$. The pattern was also different, with a higher proportion of SCFAs as butyric acid and a lower proportion of propionic acid in both the caecal and colonic content samples (Table II).

\section{CAECAL AND COLONIC TISSUE WEIGHTS}

The caecal and colonic tissue weights were significantly higher in the rats fed the higher fibre diet than those fed the low fibre diet (Table $\mathrm{I}, \mathrm{p}=0.001$ ).

\section{MUCOSAL PROLIFERATION}

The BrdUrd labelling index showed a trend for increased cell proliferation in the higher fibre rat group, which reached statistical significance in the proximal colon but not in the distal colon (Table III, $\mathrm{p}=0.05$ ). The labelling index was higher in the proximal colon than in the distal colon for both groups of rats (Table III, $\mathrm{p}<0.05$ ). Analysis of the distribution of the BrdUrd label along each crypt showed a significant shift in the population of dividing cells towards the luminal surface in both sites of the colon (Figure). The results of the flow cytometry analysis showed similar changes in the rate of cellular proliferation as the BrdUrd method (Table III) but, these changs were of smaller magnitude indicating the lower sensitivity of this method.

\section{Discussion}

In this study we have shown that long term (18 months) ingestion of $133 \mathrm{~g} / \mathrm{kg}$ dietary fibre resulted in a modest but significant increase in cellular proliferation in the crypts of the proximal colon but not the distal colon of the rat compared with an intake of $17 \mathrm{~g} / \mathrm{kg}$ dietary fibre. This was relatd to a several fold increase in the concentration of SCFA in the caecum. Caecal contents were used to indicate the composition of the proximal colonic contents since it was difficult to obtain sufficient proximal clonic contents in the low fibre diet rats to assay for SCFA. We have attributed these effects to the difference in fibre content of the two diets but some contribution may have been made by the difference in protein content as some protein may have reached the colon and also have been fermented. The higher fibre diet fed to the rats could be regarded as their normal fibre intake and thus this study compared normal fibre intake with low fibre intake. This may also be said of the fibre intake in man where we generally eat a low fibre diet but evolved eating a high fibre diet. In addition since the rats on the low fibre diet were heavier at the end of the study, although food intake measurements at 12 weeks showed no difference between the two groups, it is possible that the differences in morbidity were due a variation in calorie intake since caloric restriction is known to prolong life in rodents. ${ }^{16}$

In addition to the changes in the numbers of cells in S phase of the cell cycle, the cumulative distribution of these cells also changed so that the population of dividing cells was spread further up the crypt in the higher fibre fed rats. This occurred in both the proximal and distal colon. It has been proposed that an early event in the development of colorectal tumours is the loss of the ability of colonic epithelial cells to undergo terminal differentiation as they migrate up the crypt towards the luminal surface. This is reflected in a retained capacity for DNA synthesis which leads to an expansion (stage 1) or a shift (stage 2) of the proliferative compartment towards the upper portions of the crypt. ${ }^{617}$ In this study it seems that the higher fibre die expanded the proliferative compartment in both the proximal and distal colon and would thus appear to increase the risk of colonic mucosal cell instability. However, although significant, these changes in cell proliferation were very modest $(<20 \%$ increase) and the most marked changes in cellular kinetics were seen in the proximal colon where most of the fermentation occurred and the highest SCFA concentrations were seen. The butyric acid concentration was particularly high in the proximal colon and this has been reported to induce differentiation in colonic cancer cell lines. ${ }^{18}$ Colonic cancer in the proximal colon is very rare, most lesions occur in the distal colon. Furthermore, none of the rats developed colonic neoplastic changes in the 18 month period. This many be because the rat model was not exposed to an intiating factor or that 18 months was still not long enough to allow cancer to develop. Some of these rats (five animals in the low fibre group, six in the higher fibre group) did develop testicular cancer.

In addition to the large increases in colonic SCFAs, there were also important changes in the physical properties of the colonic contents. The luminal volume was greatly increased, and this 
was more liquid. Transit time was not measured but it would be expected to be shorter. These factors may have led to a decrease in the exposure of the colonic mucosa to carcinogens and may have protected the colon and negated any effect of the modest increases in the proliferative zone in the distal colon.

It is difficult to assess the role of dietary fibre in the development of colonic cancer ${ }^{5}$ but our results suggest that the increases in cellular proliferation associated with long term higher dietary fibre intake are modest, occur mainly in the proximal colon and are unlikely to present a significant risk for mucosal instability in the distal colon. Conversely, a low fibre diet did not lead to changes in cellular proliferation which might be associated with mucosal instability. A reduced fibre content of the diet on its own might be an important contributor to the development of colonic cancer. These experiments suggest that this is unlikely in the rat. Many other contributing factors would appear to be necessary.

We would like to thank Dr Hans Englyst for measuring the dietary fibre content of our diets.

1 Jacobs LR, Lupton JR. Relationship between colonic lumina $\mathrm{pH}$, cell proliferation and colon carcinogenesis in 1,2 dimethylhydrazine treated rats fed higher fibre diet. Cancer Res 1986; 46: 1727-34.

2 Goodlad RA, Lenton W, Ghatei MA, Adrian TE, Bloom SR Wright NA. Effects of an elemental diet, inert bulk and different types of dietary fibre on the response of the different types of the 作 to plasma gastrin, enteroglucagon and PYY concentrations
Gut 1987; 28: 171-80.
3 Roediger WEW. Utilisation of nutrients by isolated epithelial cells of the rat colon. Gastroenterology 1982; 83: 424-9.

4 Sakata T. Stimulatory effect of short chain fatty acids on epithelial cell proliferation in the rat intestine: a possible explanation for the trophic effects of fermentable fibre, gut explanation for the trophic effects of fermentable fibre, gut
microbes and luminal trophic factors. Br $\mathcal{F}$ Nutr 1987; 58: microbes

5 Deschner EE. Cell proliferation and colonic neoplasia. Scand 7 Gastroenterol 1988; 23 (suppl 151): 94-7.

6 Lipkin M. Application of intermediate biomarkers to studies of cancer prevention in the gastrointestinal tract: introduction and perspective. Am F Clin Nutr 1991; 54: 885-925.

7 Jacobs LR. Influence of soluble fibres on experimental carcinogenesis. In: Kritchevsky D, Bonfield C, Anderson JW, eds. Dietary fibre; chemistry, physiology, and health effects. New York: Plenum Press, 1990: 389-401.

8 Deschner EE, Maskens AP. Significance of the labelling index and labelling distribution as kinetic parameters in colorectal muco of ancer patients and DMH treated animals. Cancer 1982; 50: 1136-41.

9 Englyst HN, Cummings JH. Simplified method for the measurement of total non-starch polysaccharides by gasliquid chromotography of constituent sugars as alditol acetates. Analyst 1984; 109: 937-42.

10 Spiller GA, Chernoff MC, Hill RA, Gates JE, Nassar JJ, Shipley EA. Effect of purified cellulose, pectin and low residue diet on faecal volatile fatty acids, transit time and faecal weight in humans. Am f Clin Nutr 1980; 33: 754-9.

11 Wilson RG, Smith AN, Bird CC. Immunohistochemical detection of abnormal cell proliferation in colonic mucosa of subjects with polyps. F Clin Pathol 1990; 43: 744-7.

12 Bjerkness $M$, Cheng $H$. Methods for isolation of intact epithelium from the mouse epithelium. Anat $\operatorname{Rec} 1981$; 199: 565-74.

13 Dietch AD, Law H, White RD. A stable propidium Iodide staining procedure for flow cytometry. 7 Histochem Cytochem staining procedure

14 Dean PN, Jett JH. Mathematical analysis of DNA distributions derived from flow microfluorometry. $\mathcal{F}$ Cell Biol 1974; 60: 523-7.

15 Siegel S. Nonparametric statistics for the behavioural sciences. International students edition. Koga Kusha: McGraw-Hill, 1956: 131-6.

16 Kritchevsky D. Fat, calories and fibre. Prog Clin Biol Res 1986; 222: 495-515.

17 Lipkin M. Phase 1 and phase 2 proliferative lesions of colonic epithelial cells in diseases leading to colon cancer. Cancer 1974; 34: 878-88.

18 Augeron C, Laboisse CL. Emergence of permanently differentiated cell clones in a human colonic cancer cell line in culture after treatment with sodium butyrate. Cancer Res 1984; 44: 3961-9. 